\title{
The Application of Smart Class in Experimental Teaching of Foreign Language
}

\author{
Aiwu Lu \\ Zaozhuang University \\ Zaozhuang, China 277160
}

\begin{abstract}
Since the National Ministry of Education issued and implemented the "College English Curriculum Requirements" in 2004, the reform of college English teaching has been constantly deepened, and colleges and universities have generally implemented English experimental teaching based on computer and network technology. College English experimental teaching is a new kind of exploration and attempt with the help of modern information technology and based on experimental teaching method. This paper fully analyzes the teaching method of college English class based on the concept of smart class, and requires to establish an effective experimental teaching evaluation, to strengthen the effective interaction between teachers and students, to promote the full development of students' independent learning, and finally to achieve an ideal teaching effect.
\end{abstract}

Keywords-smart class; college English teaching; foreign language experimental teaching; application

\section{INTRODUCTION}

The introduction of the smart class provides a new interpretation of the current curriculum teaching methods, making full use of the current fast-growing information technology, providing sufficient support for students' learning, and being able to achieve an ideal teaching effect under the current teaching methods. It provides a new perspective for English teaching in colleges and universities, and can be fully utilized in experimental teaching methods.

\section{THE DEFINITION OF SMART ClASS}

The smart class is a new teaching method proposed in the current teaching process. It refers to the process that fully promoting the students' learning process, creating the best educational method for students' learning, timely monitoring and effectively analyzing the students' learning status, fully evaluating the students' learning methods, and providing students with various teaching resources according to their learning needs with the help of information technologies in the teaching process such as multimedia, so as to finally realize the positive development of students' learning and make different levels and stages of students learning. In the application of the teaching method of the smart classroom, the teaching approaches that teachers mainly adopt include using micro-courses and courseware, providing students with diverse cloud courses and so on [1].
The use of smart class can provide students with a variety of support from the perspective of information technology. The teaching methods adopted include interactive intelligent all-in-one machine, recording and broadcasting systems, response systems, educational cloud platforms, etc. In order to meet the teaching needs, every teacher and student is required to be equipped with a computer or use the mobile phone to make multiple connections to the Internet. The support of cloud technology is needed in the application of smart class, which enables teachers to teach at different angles according to students' needs, and provide them with more abundant teaching resources to meet the diverse teaching needs of students [2].

\section{THE MAIN POINTS OF THE SMART ClaSS IN THE FOREIGN LANGUAGE EXPERIMENT TEACHING}

\section{A. Taking Teaching as the Center as Well as Serving Teachers and Students}

In the process of applying smart classroom to college English teaching activities, we should fully concentrate on the development of teaching activities. In the experimental teaching method, various teaching methods and information technology are used. However, in the application of these massive information technology methods, teaching activities should be taken as the center and the development of teaching activities should be adopted to promote the full implementation of teaching activities. In the meanwhile, we should develop and utilize laboratory equipment fully, and maximize the role of application equipment to promote the full progress of teaching activities. In the process of using intelligent teaching methods, it is necessary to fully realize the uploading and downloading of teaching curriculum resources, actively use the teaching support platform for effective maintenance and update, fully realize the active maintenance and effective management of the server, actively and fully set up the teaching online activities, and strive to make full use of the auxiliary teaching methods [3].

\section{B. Refining Division of Labor and Improving Management Efficiency}

In the process of using smart class, there are many different teaching tasks. Compared with the traditional multimedia teaching methods, it faces more systematic management systems and management methods, which 
contain more detailed teaching contents. Based on this, it requires fully dividing the duties and responsibilities of different posts and making a reasonable division of labor in the process of using smart class into college English experimental courses. In order to provide sufficient teaching support for the experimental course teaching, it is required to fully strengthen the full maintenance and effective management of equipment, software and teaching background, as well as other methods such as the management of English courses, servers and logistics management of English classrooms. Aiming at the specific requirements of the experimental teaching to establish corresponding echelon management team and set the corresponding management tasks according to the different degrees of management difficulty, it requires the management personnel to have skilled equipment operation skills and operation modes, which enables them to pay attention to and effectively solve all kinds of problems in the process of multimedia management; besides, strengthening effective contact with outsourcing maintenance companies also contributes to making full use of instruments and equipment [4].

\section{College English Experimental Teaching System and Content}

The experimental teaching method is an important way in the current teaching process. It has a very wide application space in college English teaching, and it's a new teaching method developed in the process of college English teaching, which is very important to promote students' learning. The important performances of the experimental teaching methods mainly include a variety of teaching methods such as sound lab. The current teaching mode has a very important role in promoting students' learning. The setting of experimental teaching is mainly manifested in various components such as experimental foundation, special experimental course, comprehensive experimental course and face-to-face counseling course. The experimental teaching methods mainly include three methods: validation experimental teaching, applied experimental teaching and exploratory experimental teaching. According to the needs of the course, it is necessary to fully consider the multiple levels of teaching such as basic skills of English language learning, the basic design of English language learning and the comprehensive experiments in the process of English learning in the process of teaching activities. In the setting of college English practice courses, different colleges and universities have different ways of expression. Some teaching methods are based on the development of teaching experiment courses to set up various courses such as experimental courses for basic English listening and speaking, experimental course in basic reading, experimental courses for news development and research, experimental courses in English film and television listening and speaking, basic courses in English listening and speaking, experimental courses in English writing, experimental courses in English comprehensive projects, etc. [5].

\section{Experimental Teaching Mode of College English}

In the process of conducting the college English experimental course, various forms such as teaching content, teachers, learners and media should be fully considered. In the process of developing teaching activities, it is needed to make full use of various multimedia, and finally achieve effective teaching effects. The teaching methods adopted mainly include distance teaching methods, students' selflearning, and interaction between teachers and students after class. According to the requirements of the English experimental course, it should provide a positive and sufficient teaching platform for the students' course learning in the teaching activities, so as to realize the full monitoring of the students' learning stages and learning effects, and finally achieve the ideal teaching effect. It also requires fully respecting the status of students' teaching subjects in the teaching process, which means not only respecting students' independent learning, but also adopting teaching methods fully using computers to assist teaching. At the same time, in the process of developing teaching activities, it is required to strictly follow the relevant requirements in the "College English Curriculum Requirements", design and analyze the teaching process of students, fully respect the status of students in the process of teaching activities, make full use of modern well-developed information technology in the process of self-learning and development, and use various teaching methods such as sound lab to achieve various teaching objectives in the process of students' learning with the purpose of promoting the reading and writing of English teaching [6].

\section{THE APPLICATION OF SMART CLASS IN FOREIGN LANGUAGE EXPERIMENT TEACHING}

The application of smart classrooms in foreign language experiment teaching mainly includes establishing independent learning modes, laying equal stress on both language input and language output, paying attention to the publication, implementation and evaluation of English teaching activities, and building various network platforms to realize the network interaction between teachers and students, etc. The following part makes corresponding analysis from these four aspects.

\section{A. Establishing Independent Learning Modes}

Using experimental teaching methods to promote students' self-learning is one of the important application methods of experimental learning. In order to achieve this teaching goal, we should first of all encourage students to develop a correct learning attitude, and use multimedia learning methods to promote their full learning. There are many problems at multiple levels in college English learning. Students may face various negative emotions such as passive and loss in the process of English learning and it's difficult for them to choose proper ones but are at a loss facing a large number of English resources. It plays a very negative role in the achievement of the experimental course and should be paid enough attention. Therefore, in the present process of teaching activities, students should be guided to develop positive teaching methods. Firstly, we 
should reflect and summarize the traditional teaching methods, apply the effective teaching factors to the experimental teaching methods, meanwhile explore new teaching methods, and encourage students to study the course knowledge in small groups with the aim of helping student to complete homework independently.. The teaching methods adopted include group performance, courseware production and mutual-evaluation within groups. The selflearning mode has a very important positive effect on the students' learning. Compared with students in junior and senior middle schools, students in university should adopt more independent learning mode and give full play to their dominant position in the learning process, which is consistent with the teaching philosophy of smart class. The application of experimental teaching method can realize this teaching goal.

\section{B. Laying Equal Stress on Language Input and Language Output}

The development process of the network information platform is fully integrated into various rich teaching cases and learning resources, providing a variety of perspectives for students' language learning, and finally making full use of students' good language input methods. Effective experimental activities help students carry out corresponding effective teaching activities, provide comprehensive guidance for students' learning, and create audio and video recordings of student curriculum activities. Various teaching activities also help students to achieve good learning results.

While implementing language input, we should strengthen adequate guidance of students' language output methods, pay equal attention to the input and output of English learning, establish an evaluation teaching system that integrates evaluation criteria, evaluation forms and evaluation subjects, fully realize the diversification of evaluation subjects, make an effective breakthrough in the traditional teaching method only centered on teachers, and strive to realize the mutual evaluation among students so as to promote the mutual feedback among students.

\section{Paying Attention to the Publication, Implementation and Evaluation of English Teaching Activities}

The development of the College English Experimental Course requires full attention to the publication, implementation and evaluation of English teaching activities, and the comprehensive evaluation of Yingnuo teaching. Firstly, it requires that the English teaching platform can fully meet this requirement and personalize English teaching activities. In the process of designing, it is required to make corresponding teaching plans and guidelines according to the differences of students' learning foundation and learning degrees, and formulate corresponding teaching methods for the setting of teaching content. Secondly, implementation process of teaching experiment activities is mainly reflected in the interaction between teachers and students. Teachers should design different teaching contents according to different contents of teaching practice, be able to introduce corresponding different activity cases, and promote English teaching for students by means of the construction of sound laboratory. At the same time, in the process of developing the teaching activities, teachers should try to fully evaluate the students' experimental courses, give timely feedback on their learning effects, and formulate sufficient teaching tasks for the students' course learning to achieve the full storage of teaching content as well as make up a good and sufficient language experiment for students' learning activities so as to achieve the ideal teaching results ultimately.

The implementation of teaching evaluation method can fully achieve students' ideal teaching effect, which helps them to fully summarize as well as analyze their own learning effects and encourage students to write study journals. By reading the students' study journals, teachers can timely find out the problems students encounter in the learning process so as to achieve a good teaching effect. Besides, a good teaching evaluation system for students should be formulated, and it can be phrasal, text or speech in the way of evaluation. For students who have achieved a better learning effect, their learning process and methods can be taken as teaching cases to encourage others to study.

\section{Building Various Network Platforms to Realize the Network Interaction Between Teachers and Students}

Applying the teaching concept of smart class to the college English experimental teaching activities requires establishing the network platform for experimental teaching methods fully. Currently, the widely used network platforms mainly include online English radio, online course learning, network television stations, and English learners Blogs, etc. The establishment of these online teaching platforms can promote the benign learning of college English from many aspects and strive to realize the independent learning of students, so as to realize the benign development of students. It is required to make full use of the rapidly developing information technology in the process of language learning guidance, English listening and English reading. The application of this method can also fully observe and analyze the students' self-learning status, and ultimately ensure that students can achieve good learning results. In terms of specific construction methods, it mainly includes the establishment of college students' independent learning network monitoring system and evaluation system, and the corresponding adjustment and improvement according to the specific development needs of students. According to the needs of intelligent teachers, it is required to establish a sufficient network office automation system, so as to effectively improve students' learning conditions, and finally make full use of various teaching modules, such as English reading, English listening and English writing. This is the need for the establishment of experimental English courses in colleges and universities, and also an important way for setting intelligent professors. It is an important guarantee for improving the efficiency of English teaching activities to fully realize the network development of students' learning and promote the real-time and networking of teacher management. 


\section{CONCLUSION}

The use of smart class can make full use of the teaching management process and management tools, and encourage students to develop good learning habits, fully and effectively guide students' study and life, and have extensive teaching resources. Applying the teaching concept of smart class to the teaching process of college English experimental courses can promote the improvement of students' independent learning ability and learning consciousness. The full establishment of the teaching platform can achieve good communication between teachers and students, take the development of teaching activities as the center, and achieve sufficient and effective teaching guidance for students.

\section{REFERENCES}

[1] Cui Xiaoying. Effective Application of Smart Class Software in English Classroom Teaching in Elementary Schools [J]. Bosom Friend Inspiration, 2017(9).

[2] Zhang Yi, Chen Beilei, Li Xiaoyan, et al. Research on Design and Application of iPad Electronic Textbook Based on APT Model in Smart Class_- Taking Toby's Dream in the First Volume of English in Grade 5 of Primary School as an Example[J]. E-education Research, 2016( 8): 63-71.

[3] Jin Jie. Case Analysis of Interactive Reading Teaching of Middle and Vocational English Based on Smart Class [J]. English on Campus, 2016(20): 71-72.

[4] Dai Jianli. Research on Interactive Teaching of English School-based Curriculum in in the Environment of Smart Class [J]. New Course (2), 2017(7): 14-15.

[5] Yang Chao. Application of Smart Class in Mathematical Interactive Teaching in Primary Schools[J]. China Educational Technology \& Equipment, 2017(19): 52-54.

[6] Luo Meilan. Application Analysis of Smart Class in Mathematics Teaching[J]. Kaoshi Zhoukan, 2017(26): 32-33. 